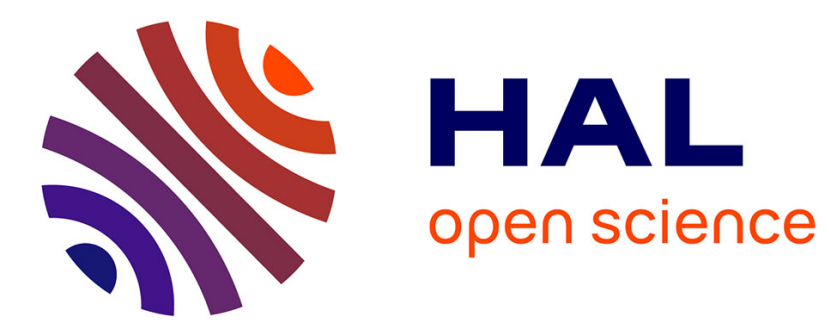

\title{
Vertical Living and the Garden City: The Sustainability of an Urban Figure
}

\author{
Xavier X. Guillot
}

\section{To cite this version:}

Xavier X. Guillot. Vertical Living and the Garden City: The Sustainability of an Urban Figure. TaiChee Wong; Belinda Yuen; Charles Goldblum. Spatial Planning for a Sustainable Singapore, Springer, pp.151-167, 2008, 978-1-4020-6541-5. 10.1007/978-1-4020-6542-2_9. hal-03487067

\section{HAL Id: hal-03487067 https://hal.science/hal-03487067}

Submitted on 17 Dec 2021

HAL is a multi-disciplinary open access archive for the deposit and dissemination of scientific research documents, whether they are published or not. The documents may come from teaching and research institutions in France or abroad, or from public or private research centers.
L'archive ouverte pluridisciplinaire HAL, est destinée au dépôt et à la diffusion de documents scientifiques de niveau recherche, publiés ou non, émanant des établissements d'enseignement et de recherche français ou étrangers, des laboratoires publics ou privés. 


\title{
Vertical Living and the Garden City: The Sustainability of an Urban Figure
}

\author{
Xavier GUILLOT \\ Professeur à l'Ecole nationale supérieure d'architecture et de paysage de Bordeaux \\ Chercheur à l'UMR 5319 Passages, Université Bordeaux Montaigne
}

In Europe, the debate on sustainable urban development in housing has led to the formulation of a set of generic questions regarding the future of human settlements in the context of a society which is becoming more and more individualistic and mobile. The movements associated with this debate are more and more complex to foresee. In this debate, re-evaluating the sustainability of existing urbanization processes and settlement patterns, as developed during the 20th century, is at the top of the planner's agenda. For European urban planners, one of the main tasks is to find an alternative to worldwide processes occurring around cities known as urban sprawl, i.e. the development of individual housing as a dominant dwelling type and the use of automobile as its "domestic extension". In this context, alternative housing programmes appeared in the last two decades offering a more environmentally friendly solution than the "individual house + car package". This solution tends to re-examine the "ecological potential" of traditional form of dwelling that optimizes local services and minimizes automobile transport'.

Parallel to these experiments in housing, alternative planning schemes at the scale of the territory involving the concept of sustainability is also on the planner's agenda. For example, master plans recently designed for the area of ljburg in Amsterdam, Bjorvika in Oslo or Orestäd in Copenhagen "ii are representative of these attempts as each suggests a specific geographical strategy defining the relationship between human and the territory. One of the main goals is to contain ecological nuisance in low density residential development around cities driven by the market. Relationship with nature is of prime importance in the definition of these schemes. Master plans are associated with a specific landscape design in which the relation between built areas, transport infrastructure and natural environment is considered through a specific scenario leading to the formulation of a recognisable spatial scheme. For some analysts (Marcillon and Ali 2006 for example), one beneficial aspect of designing such a recognizable spatial scheme is its capacity to convey the "geographical memory" of a place, as well as to carry its future for its inhabitants and visitors. It is in this sense that they are called "sustainable urban figures".

At first glance, this type of planning approach may be interpreted as outdated by its ambition to associate in the long term the future of a place through a master plan and a specific spatial scheme. Indeed it is possible to read this scheme as an attempt to rehabilitate planning doctrines inherited from the 19th century, leading to the formulation of a model. Contrary to this first reading, the goal of these master plans is not to formulate a 
model which can be reproduced from one place to another. In the above mentioned examples in Europe, sustainable planning is taken as an "open concept", leading planning design goals to be reformulated according to each place. This is why each urban figure mentioned above is not only induced by specific indicators of sustainable development. They are also the result of a combination of different parameters taken from the analysis of a specific context. According to this approach, sustainable planning is primarily a "cultural" and political approach in the formulation of goals regarding the physical evolution of a place.

\section{Introducing the case of Singapore: the Ring City and Garden City concepts}

It is with this cultural approach that the notion of sustainable development will be examined in the case of Singapore. This city-state constitutes a remarkable study case in this domain. Right from the time it gained its independence, governmental decisions to transform the colonial city core and its hinterland into a modern city-state were associated with a set of planning concepts, two of which have proved their durability in the implementation of a spatial entity at the scale of the island: the "Ring City" and the "Garden City".

The "Ring City" concept originated in the Netherlands where a group of major towns, including Amsterdam, Harlem, Utrecht, Delft and Rotterdam, form a large circle around a central stretch of open country that is used for water collection, food production, recreation and fast flowing traffic. It was introduced in Singapore in 1963 by a United Nations planning team, led by Professor Otto Koenigsberger, a German architect-planner and Housing Advisor to the UN Economic Commission for Africa. Although largely revised and reformatted by the subsequent "concept plans", this original spatial planning scheme remains valid. Since its implementation in the early 1970s, the old colonial city of Singapore was progressively "atomized" to be part of a "ring" of new settlements connected with each other by a modern transport system, the MRT, the center of the island being kept as a natural reserve for water catchment.

In 1963, the same year as the "Ring City" concept was launched, Lee Kuan Yew, in a farsighted and intuitive action, launched the "tree planting campaign". As Koh Kheng Lian (1995) said: "the 'seeds' of the garden city were planted ». Five years later, on 16 December 1968, the concept of "garden city » was officially introduced during the passage of the second reading of the Environmental Public Health Bill, when the then Minister for Health, Mr Chua Sian Chin, in considering the Environmental Public Health Bill, said: "The improvement in the quality of our urban environment and the transformation of Singapore into a garden city - a clean and green city - is the declared objective of the Government ( Lee 1995: 130). Today, the "garden-city » concept is still a constant reference to orient the planning strategy of the Singapore government and has proved remarkably durable. In this context, it is legitimate to question the use of this concept and the meaning it has in the context of Singapore. 


\section{A Sustainable Urban Figure "Made in Singapore": The Garden City}

The use of the term "garden city" is borrowed from the planning concept, formulated by Ebenezer Howard in the early 20th century in his book: Garden Cities of Tomorrow (1902). Because of its European origin, the use of the concept in Singapore implies a "cultural transfer" form the West to the East. On this matter, Charles Goldblum (1988) explains that the use of this concept in the case of Singapore reflects that "of all the social and built environment forms which emerge in England, the theme of the garden city manages to find its application outside the industrial society of the European metropolis, in its "overseas extension": in the compact and overcrowded Asian cities, that simultaneously appear to be symbolically the equivalent of the working district of Europeans cities". iii In principle, one should briefly recall that planning and implementing a garden city as defined by Howard involved the preservation of a green belt for food production for its population and to prevent the physical connection with the industrial city. In this sense, a typical garden city tended to be self-sufficient. It was limited by the size of its population: 30,000 inhabitants, plus 2,000 farmers in the green belt ${ }^{\text {iv }}$.

Obviously, the definition of garden city concept, as defined by Howard, does not match with the reality of Singapore. After forty years of intensive development, Singapore is not a discrete and self-sufficient settlement, which is limited by its population. The question therefore is to understand why and how Singaporean planners and government choose to operate this cultural transfer form Europe to Asia to determine planning guidelines for the future of Singapore. The city of Queenstown (Queenstown Industrial and Housing Estate), started by the colonial government at the beginning of 1950, gives clear indications of how Howardian ideas were locally received and reinterpreted.

In its early phase, Queenstown was designed along the same lines as British new towns, according to the principle of neighborhood unit that would preserve privacy thanks to its low density. However, from the 1960s, a radical transformation was carried out in the planning strategy. A high density housing complex was later built (1000 people/ha), in order to face the severe housing shortage. Subsequently, this planning option would be applied to all new settlements, contributing to the promotion of what would become the main dwelling form for Singaporeans: the apartment block of 10/15 storeys, also called "slab blocks", which later were transformed into a higher building in the form of towers of 25 storeys (point blocks).

Accordingly, "garden city", as used by the government, suggests a different interpretation of the Howardian concept. It does not refer to the construction of a low-density, selfsufficient settlement in which industry and farming provide a balanced environment. To the contrary, it matches the reality of an urbanization which tends towards high-density development rather than low-density, high dependency rather than self-sufficiency through

its multiple economic connections as a global city. Underlying this evolution in the reinterpretation of the Howardian concept, there are two historical and geographical facts. 
First, the fact that we have entered another economic era, but moreover, the fact that Singapore urban growth has entirely occurred on a limited territory and, due to the constant awareness of lack of space, the choice of high density construction.

While maintaining this historical reference to the Howardian concept, it is another planning doctrine which was implemented. It is a model that historically finds its roots in France and Germany rather than in England, and which directly refers to this "modern order" (Sota 1994) that was defined by the CIAM protagonists in the early 20th century. For these reasons, as in the example of European cities described above, references made to the double use of the "Ring City" and "Garden City" concepts are representative of the durability of a planning strategy which, in the long term, has oriented the geographical relationship between housing and the territory. Up to the present, despite the increase in population and the non-extendable area of the territory, the catchment area in the centre of the island has been preserved. Construction regulations of apartment blocks in new towns have prevented urban sprawl from developing. Nowadays, individual housing or largely known as "landed properties" in Singapore represents a small proportion of the housing stock on the whole island.

As Victor Savage (1991) correctly suggests, the concept of Garden City, as it is now interpreted and used by the Singapore authority, must be perceived as a kind of " neoutopian ideal " to be reached. It is representative of the search to identify a global urban environment, where the daily-life setting, shaped by humans, would be inscribed in a large garden shared by the whole Singaporean population ". Looking back at the previously mentioned examples in Europe, the question now is to understand the characteristic of this urban figure reflecting this neo-urban ideal, and simultaneously to define and comprehend the main planning mechanisms allowing its sustainability.

\section{Verticality and Greenery: Achieving the "Modernist Dream"}

Construction in the 1970s of the first HDB 25-storey five-room-apartment tower, also called "point block" apartment, can be seen as the beginning of a movement which has since become common: that is, towards what we call here a process of "verticalisation" of its housing stock. Although few examples still exist, such as the Forfar House built by the Singapore Improvement Trust, it is from this decade that Singapore housing policy is closely associated with the construction of the apartment tower on a large scale.

Indeed in comparison to the 15-storey slab blocks mentioned earlier, the point block building represented a significant evolution in the design of apartment buildings. All architectural characteristics recalling the spatial organization of the traditional city are erased. The relationship between land and building along a street, inducing simultaneously a specific orientation to the apartments, is obsolete. The building becomes independent of land. Simultaneously, land is given another status and function which tends to promote this idea of becoming a large garden. Regarding this fact, Sumiko Tan (1999) writes: "With 
more homes being built near parks, garden and recreational areas, you don't need to have a garden to enjoy living close to the nature ....". One should understand here that the need to have a garden linked to a private house would inevitably involve urban sprawl.

In other words, the reference to the "garden city" as a neo-utopian ideal is used to specify a double planning process in the transformation of the built environment involving on one hand the "verticalisation of housing" at the scale of an island, and on the other hand an ongoing process of transformation of its landscape to optimize greenery as a public resource including land reclamation to extend the island territory. In this domain it is crucial to mention the work conducted by some government bodies, in particular the Parks and Recreation Department or the National Parks Board, to name a few. As Koh Kheng Lian (1995) points out: "Without effective administration and financial support from the Government it would not be possible to implement the Garden City Concept".

More than three decades after the first HDB point block buildings were erected, the choice made by the government to associate "vertical living" and "green landscaping" proved its longevity as a planning tool to develop a sustainable urban figure. Nowadays, a very large majority of Singaporeans live in high-rise buildings and identify themselves with this urban setting. Although having been distorted, reference made by the Singapore authority to the Howardian concept, remains consistent, as it acquired a symbolic status in the mind of the population regarding the undergoing transformation of their city. It meets this neo-utopian ideal mentioned earlier by Victor Savage by associating its future with the construction of a large garden in which all the nuisances of the city would disappear.

The question now is to understand how Singapore planners manage to sustain this dwelling model considering the diversity of the demand. Indeed, since the 1970s Singapore society has greatly evolved. The time when the population had to face housing shortages and precarious comfort has been left behind. Instead, Singapore has emerged as a so-called "middle class society" and the level of income is comparable to developed countries.

In this context, one of the key questions which needs clarification is how the government manages to match both the fast transformations of cultural values and aspirations of society with the continuity of planning strategy that portrays a durable urban figure. Alternatively, it is how the government manages to introduce adjustment mechanisms to renew the first models as designed and implemented in the 1960s. In response to this, the notion of housing sustainability is approached via a social dimension which is reflected by the capacity of its policies and programmes to include ongoing social changes and lifestyle values, in particular those related with the growth of the middle class. In this process, the increased involvement of private developers in the evolution of the housing stock will play a major role (Wong and Guillot 2005). 


\section{Sustainable Development as a "Multidimensional Recycling Process"}

One of the entries to understanding this adjustment mechanism and the specificity of the Singapore approach is to look at the destiny of the housing stock built during the two decades which followed independence and, simultaneously, to compare it with the European experience. In Europe, and in particular France, demolition programmes have been implemented on a large scale in order to replace post-war housing apartment blocks. In comparison, such demolition in Singapore is rare. It only applied to a restricted housing stock that was built with minimum comfort in the years immediately after independence.

Indeed, during the last 40 years, the government has favoured a constant "adaptation" of its historical model of vertical living chosen to meet a new demand, rather than introducing radical change. It is here that a specific approach of Singapore planning strategy emerges, in which recycling appears to be central to the various dimensions it applies to. In this perspective, the question is therefore to identify the mechanisms which characterise this recycling process. It will be reviewed in three entries corresponding to three directions taken by the government, the URA in particular, to extend vertical dwelling.

\section{Recycling Process 1: Extending Vertical Living Island-wide through Privatisation}

The first important measure taken by the government to maintain this planning goal was to extend vertical living to the private sector in order to satisfy a demand coming from expatriates, as well as from the rising middle-class groups who, given an option, would generally invest in landed properties. This extension was possible through the launch in the late 1970s of the condominium formula. Completed in 1976, Futura Tower is one of these first buildings marking the extension of vertical living to the private sector based on the condominium design guideline elaborated by the URA. The idea is to abandon the traditional functional separation between dwelling and urban facilities and services, and to propose a more intensive use of the land with the presence of various sport and leisure facilities within the condominium parcel ${ }^{\mathrm{vi}}$.

By the verticality of the building and also by the minimum impact it has on the land, the continuation with the Garden City concept is confirmed. Indeed, the possibility of building up to 30 storeys, combined with relatively high plot ratio (2.8) and the requirement that the building should not occupy more than 20 percent of the land parcel, largely determined the final design: a high-rise apartment block of 26 floors. Its architectural feature is largely founded on past models, in particular the HDB point-block as described earlier. It has the same principle for distributing the apartment around a central core comprising the vertical circulation. Simultaneously, the condominium benefits from the architectural and technical know-how required to design a high structure similar to office towers that were simultaneously built in the central business district. Besides high design standards for the 
apartment (size, finishing, etc) the extension of vertical living to the rising middle-class is therefore associated with the introduction of the principle of 'multi-purpose urban housing'.

Extension of vertical living to the middle class had important consequences on the geographical repartition of the housing stock at the scale of the island. During the 1990s, condominium production equaled almost one-third of the public housing produced by the HDB, whose rhythm of production had, to the contrary, decreased considerably ${ }^{\text {vii }}$. This slowdown in the construction of public housing is the consequence of the change in HDB policy guided by the publication of the Revised Concept Plan. The objective is effectively to reach a new balance in the ratio between public and private housing. In 1980, condominium's share was less than 1 percent of the HDB share. In 1999, its share rose to 8.3 percent. By 2002, the ratio of condominium to HDB units rose to slightly less than 10 percent (Department of Statistics 2001, 2003) (see also statistics in Appendix 1).

As a logical consequence of the spectacular increase in the construction of condominiums, one observes the inversion of the ratio between individual housing and apartment buildings in the private residential stock, producing an outcome fulfilling one of the key objectives of the government ${ }^{\text {viii }}$. These results show how the government and private investors manage to reach the goal to promote vertical living at the scale of the island in order to facilitate the construction of a specific landscape where large green private and public are prominent. However beyond the quantitative figure, one should understand the territorial impact resulting from the increase in numbers of condominiums according to which location/logic it follows. The main issue here being: how the extension of vertical living to the private sector interacts with the urban figure inherited from the Ring City concept plan.

From the 1970s until the end of the 1980s, the majority of condominiums were located within a five-kilometre radius around the city centre as exemplified by the Futura Tower. Through its Sales of Sites Programme, URA favoured condominium construction in the city centre by selling sites in Districts 9,10 and 11: a logical choice in terms of marketing strategy for private developers considering the advantages given by the proximity of the CBD and the commercial district in terms of employment and services. From the 1980s, the original concentric development pattern, leading to the spread of condominiums to outlying areas is shattered. With the development of road infrastructure, in particular urban highways, and the rising land prices in the city centre, the choice of condominium follows a new set of location criteria. In this context, along with the growth of the real estate market, one witnesses the formation of linear-shaped residential settlements located outside the city centre called condominium belts.

In general, the location of these settlements matches with a unique natural site, and a set of modern facilities, all easily accessible by automobile with an efficient network system. 
After almost three decades, one observes the presence of three of these types of settlement each with its own character:

a) The Bukit Timah Condominium Belt which is attributable to its proximity to Bukit Timah Nature Reserve, Singapore's tallest hill. In addition to this natural attraction, the presence of two highways, the Pan-Island Expressway and the Bukit Timah Expressway, allows easy access to the city centre, as well as to Jurong industrial estate and to Johor Bahru in Malaysia.

b) The East Coast Condominium Belt, which is served by the East Coast Parkway connecting the city centre to the Changi Airport. It also has a natural element which makes this residential area unique: the proximity of the sea and beach. This park comprises sport and leisure activities: playground area, cycling paths and seafood restaurants.

c) The West Coast Condominium Belt which is accessible by both the old Pasir Panjang Road and the Ayer Rajah Expressway. The advantage of this condominium belt is its proximity to key employment areas -- the city centre, Jurong industrial zone, the Singapore Container Port, and the potential Silicon Valley of Singapore: research and development activities in the Singapore Science Park and the National University of Singapore (NUS).

Since the year 2000, condominium construction through the development of condominium belts has entered a stage of "maturity". In many ways this type of housing settlement complied with the "neo-utopian ideal" to build a garden city, to quote again V. Savage. It brought housing close to the nature wit the presence of parks or natural reserve these belts are generally linked to. One remarkable aspect of this evolution is that the other planning ideal - to build a ring city - is not left behind. As the Concept Plan 2001 shows, in the next decades, the transformation of the territory will be associated with the construction of an extensive rail network that will increase the $93 \mathrm{~km}$ of rail lines to about $500 \mathrm{~km}$. Beside the construction of new radial lines such as the one recently completed to connect Pungoll to the city centre, this network comprises two "orbital lines", allowing travel from one end of the island to another - and from one condominium belt to another without going through the Central Area. This infrastructure construction program "pushes" the concept of the Ring City to another stage while remaining perfectly "faithful" to it. It links the old centre to an outer railroad ring. Simultaneously, it reinforces Singapore's land transport policy to minimize the dependence on car travel within the island, by offering island-wide rapid transit.

Recycling Process 2:

"Vertical Living" and "Green Landscaping" -- A Multi-scale and Multi-goal Programme

In the 1990s, parallel to the government's effort to promote private condominiums to meet a demand coming from wealthy households, improvement works were conducted on existing new towns and on the public housing stock. This improvement work, known as the 
"upgrading programme", started in the 1990s and applied to more than 370,000 units. Its objective was to improve the standard of comfort of apartments built between 1960 and 1970 to match the latest evolution in architectural design. Although by the HDB, the private sector was largely involved in this programme. Various degrees of upgrading work were identified, taking into account the date of construction of the building. Only the so-called Redevelopment and Selective En Blocs Renewal (SERs) Programme includes possibility of demolition ${ }^{\mathrm{x}}$.

The process of upgrading also includes urban design work. Specific outdoor facilities are added in all upgraded new towns in order to mark a hierarchy between the buildings and to break the homogenous and monotonous new town built environment. Simultaneously, the precinct concept ${ }^{\mathrm{xi}}$, introduced in the 1980s, was extended to older new towns, to soften the homogeneous and anonymous urban landscape produced by the former planning concept of neighbourhood unit. The first new town, which reflects the model rather well, is the Tampines New Town. The objective of the precinct concept is to design a cluster of apartment blocks with well-defined spaces and facilities for the 400 to 800 dwelling units, to help foster community development. It is also a strategic tool to keep green open spaces that reinforce the image of a garden city. Each precinct entrance is equipped with a porch and covered ways linking different buildings, providing protection from rain and sun, and which also mark the perimeter of each precinct and emphasize the feeling of belonging (Tan 1997: 8). By adopting this form of development, the precinct becomes the basic building block in the overall new town concept. It repeats itself in clusters of 4 hectares $(200 \mathrm{~m} \times 200 \mathrm{~m})$ or sometimes half this size. Some of the commercial facilities are redistributed within these centres.

Along with this work occurring on the existing housing stock and outdoor areas, another type of action led by the government is carried out in order to raise the new town image to that of a more up-market residential area. It is to introduce private housing within the perimeter of the New Town. Vacant plots of land were sold to the private sector through the Sale of State land. In this case, the government's objective is to change the prevailing segregating arrangement between new towns and the rest of the territory. To reach this goal, a new type of housing called the executive condominium was launched in 1996. Its design principle is largely inspired by those of a private condominium.

Again, it is from an existing type of housing that the government planned this evolution, by recycling the condominium formula to make it accessible to a lower budget and larger population. Primarily, the Executive Condominium Housing Scheme was designed to broaden the private housing stock and provide access to households whose monthly income must not exceed $\mathbf{S} \$ 10,000$, and who aspired to own private housing but could not afford it ${ }^{x i i}$. Thus, the scheme is intended to respond to the government's objective to extend private housing to a larger population, as they are sold at a cheaper price on the real estate market than private condominiums. This objective is achieved through indirect 
financial assistance of the state, in this case the HDB, by selling land to government-linked companies, such as Pidemco Land, NTUC Choice Homes, Singapore Technologies, Capitaland or to private developers at lower than market prices. In turn, these companies are obliged to sell apartments at a lower price than private condominiums.

The first two executive condominiums are located in Pasir Ris and Jurong East new towns, and were financed by Pidemco Land, Eastvale (312 units) and Westmere (280 units) respectively. They were both started in 1996 and completed two years later. Good response to the first two projects saw in 1998 the construction of the third executive condominium, Simei Green, financed by NTUC Choice Homes. In view of this success, the HDB has since accelerated the rhythm of sale of land allocated to this type of housing. In 1997, indeed, 10 additional sites were sold in new towns: Bukit Panjang, Choa Chu Kang, Tampines, Sengkang, Woodlands, Jurong and Hougang. Since this date, the sale of land for construction of executive condominiums has continued at a steady pace in order to realise about 4,000 units per year.

The two planning schemes and recycle processes described above, which contribute to recycle "vertical living", must be associated with other measures to improve the presence of nature to fit the requirement of the Garden City concept. As the concept plan 2001 (URA 2001: 23) specifies, a significant increase of green areas will cater to the recreational needs of a large population. Unlike the 1991 Concept Plan that envisaged new towns at Pulau Ubin and Lim Chu Kang, the Concept Plan 2001 plans to keep this and other existing nature areas in their rustic state as long as possible. Moreover, it aims to almost double the amount of green space from 2,500 ha to 4,500 ha. The additional open space to be provided is equivalent to another 34 Bishan Parks. Parks will have distinctive characters with distinct activities and outlook.

In addition to the increased green areas at the scale of the island, various micro planning schemes will contribute to the same goal at other levels. The "Park connector scheme" is one of the micro tools that will be used. The aim is to make green spaces more accessible. Park connectors are linear open spaces proposed by the National Parks Board to link major parks, natural reserves, natural open spaces and other places of interest in Singapore. These connectors will be mainly along drainage reserves linking the population centers and transportation nodes with the major parks. Upon completion they will form a green network over the whole island (Oi 1998). The park connector network will be extended to link parks with town centres, sport complexes and homes.

At the building scale, three significant regulations have been implemented since the year 2000, allowing the increase of green areas:

a) The first is the incentive to provide larger balconies areas to be planted. It is based on a regulation introduced in 2001, allowing residential and hotel developments to add 10 $\%$ surface area over and above the allowed development intensity. Before this date, developers had to reduce space from other areas (e.g. bedrooms) in order to provide space for balconies. 
b) The second regulation concerns the treatment of the building roof tops. In 2003, the URA relaxed the guidelines on gross floor area (GFA) exemption for rooftop pavilions. Rooftop pavilions with up to $50 \%$ of its perimeters enclosed will be eligible for the GFA exemption. Furthermore, the overall height control for developments with complete sky terrace floor was also relaxed to offer greater design flexibility (URA 2004: 37).

c) The third regulation concerns the bottom part of the building and is called "landscape deck". In 2004, the URA introduced the landscape deck as an alternative building form to residential flats and condominium development. It throws up new possibilities to improve the provision of greenery and communal facilities for flats and condominiums (URA 2004: 52).

\section{Recycling Action 3:}

"Reconceputalizing" the HDB Heritage to Match the Aspirations of a Post-industrial Society

Government plans involving the renewal of the housing stock to meet the changing demand goes beyond the earlier prescribed actions. It also includes the elaboration of planning concepts to renew the new town planning fundamentals as they were implemented until the 1980s. As described above, since the construction of Queenstown, the original planning concepts that guide construction of a new town have constantly evolved. The 1990s marks a new step in this process with the launch by the HDB of the construction of Pungoll $21^{\text {xiii }}$.

The first difference is the choice of Pungoll's location along the coast to take advantage of its natural features, as URA (1998: 12) presents their sensation of a city endowed with 'scenic views and extensive waterfrontage'. But besides this location choice, planning guidelines mark a significant step in the new town design. The plan of the new town is to implement a grid system for the road network for distribution of buildings and facility. To a certain extent, one can see in this plan an attempt at extending the planning principle applied to the city centre: large-scale road network characterised by a four or six-lane highway dominates, lined by high-rise buildings. The smaller scale road network, as found in earlier new towns, has disappeared.

Another particularity of Pungoll 21 is to increase the role of private developers in line with the objective to meet the changing social demand mentioned earlier. The distribution between public and private is planned along the following proportions ${ }^{\text {xiv }}$ : a) 60 percent public housing by HDB; b) 30 percent private housing (private condominiums, terrace and semi-detached houses); and c) 10 percent executive condominiums.

The presence of private housing has an important effect on the physical arrangement of the new town. Private condominiums are given a better location and are systematically located at the periphery, close to the sea, while public housing is located inland near the Mass Rapid Transit station and along the Light Rail Transit Network. This mix of private 
and public housing has important consequences on built intensity and height. According to the New Town master plan, HDB buildings and executive condominiums (70 percent of the entire new town) are high-rise which reinforce the vertical building landscape.

Another important characteristic that marks a difference with previous new towns is the fact that Pungoll 21 is entirely residential and does not include an industrial estate. This planning principle is a reflection of the changing economic activity towards services. In line with this evolution, since the 1990s, state intervention in the development of self-contained settlement in which the condominium is the architectural founding element, has developed on a larger scale. Tanjong Rhu and Sentosa Cove are two residential developments which reflect this new planning strategy. Taken individually, each demonstrates that the condominium can be a generator of large high-rise residential areas in the same manner as HDB blocks generate the new town space. But each of these projects reveals differences in their architectural characteristics, making them a true alternative to the HDB new towns as well as to condominium belts because of the rapidity of their construction.

Tanjong Rhu development is on the city centre's immediate fringe. The site is a long strip of land covering 34.5 ha of which 5.6 is reclaimed land. It is bordered on one side by the East Coast Parkway, which leads to the city centre and on the other side by the Kallang Basin. The site was cleared of its industrial activities to be replaced by a residential one with 3,500 units. There is maximum accessibility on one hand, and optimal attractiveness on the other, endowed with the presence of water. Taking over a relatively vacant site, planning process is similar to that of a new town where infrastructure, housing and facilities are developed from scratch. However, the planning goal as defined by the URA is radically different: it is to implement a residential area entirely dedicated to sports and leisure: a resort city in the heart of the River District ${ }^{\mathrm{xv}}$.

As in Tanjong Rhu, Sentosa Cove planning concept also emphasizes the sport and leisure activity. It is located on reclaimed land in the continuity of the development of Sentosa Island, which is now well known as Singapore's main entertainment park. The planning goal is to build housing by the sea, and in addition, due to its distance from the city centre, to provide 'the opportunity for people to fully experience the ambience of island living' (URA 1996). Currently under construction, except for two high-rise condominium blocks sited on each side of the main access point by sea, it is planned to be a low- to mediumdensity residential area (with 2,000 condominium dwelling units, in addition to the 300 bungalows and 150 terrace houses). Sentosa Cove is therefore a kind of small marina new town. On a smaller scale, a similar type of settlement has recently developed on the land formerly used by Keppel shipyard in Telok Blangah. 


\section{Tackling the Next Challenge for the Future of a Sustainable Figure: Some Concluding Remarks}

Despite all these measures taken by URA planners in order to bring nature and humans closer, in line with the Garden City concept, up until now, designs at the building scale do not seem to have reached the same degree of innovation. Generally, condominium designs seem to have reproduced a model largely formulated along the first example such as Futura Tower, constructed in the late 1970s when environmental issues were not yet a concern. Until now, experiences towards the production of a more environmentally-friendly architecture are almost non-existent. Moreover, the circulation of architectural models on the world-scale, influences design scheme towards homogenization. Simultaneously, the specificity of the local concept is ignored, in particular, the climate (Guillot 2006).

The current early phase of the 21 st century may be the time of an important change in this domain although evolution will be more incremental than radical (due to the additional costs incurred in construction of a more environmental friendly architecture). In 2000 the URA set up the Design Guidelines Waiver Committee (DGWC) "to evaluate development proposals of high quality and innovation that may merit deviation from the urban design guidelines and standard development control requirement. The scope of waiver of DGWC includes aspects such as building form and building height (except for technical building height)" (URA Skyline, May-June 2005)

The Rivergate development, a residential project on a landmark site along Singapore River, has benefited from this flexibility based on innovative design approach: it is a 43storey block while the existing guidelines required the block to be no more than 10 storeys. The innovation is based on extensive use of greenery that is integrated with the building from the base to the roof and on its entire "envelope". The building is provided with balconies and generous planter boxes and contrasts strongly with the full glazed façade that characterizes the latest design trend of condominium. In one way it is an update of some innovative and rare examples that were built in the past along similar ideas, such as The Collonade by Paul Rudolph. The next step appears to give more self-sufficiency to the building in terms of energy dependency, such as experimental towers which are now on the agenda in other cities.

With an abundance of yearlong rainwater and sunshine, one may think that the heyday of condominium has not yet been reached and hope that the next recycling process of designs to improve vertical living will include this design evolution and the ecological factor. 


\section{BIBLIOGRAPHY}

-Goldblum, C., 1988, Singapour (1819-1986): Emergence de la ville moderne et mythe rural. Villes d'Insuline 1, Special issue of Archipel (E.H.E.S.S.) 36: 227-270

-Guillot, X., 2006, Flux économiques, transferts d'expertises et production immobilière haut de gamme en Asie orientale. Géocarrefour (Volume entitled 'Expertises nomades. La circulation des modèles urbains hors du monde occidental). 80 : 171-181

-Koh Kheng Lian, 1995, The Garden City and beyond: The legal framework. In: Ooi GL (ed) Environment and the city: Sharing Singapore's experience and future challenge. The Institute of Policy Studies/Times Academic Press, Singapore, pp 148-170

-Marcillon, D., Rebois, D., Younès, C., 2006, Figures urbaines du durable. Urbanisme $348: 54-56$

-Oi Keng Hunt, 1998, Park Connectors. In Yuen B (ed) Planning Singapore: From plan to implementation. Singapore Institute of Planners, Singapore, pp 31-42

-Savage, V.,1991, Singapore Garden City: Reality, symbol, ideal. Solidarity Issue: 131-132 -Urban Redevelopment Authority URA, 1998, The Punggol Planning Area: Planning report. Singapore

-Urban Redevelopment Authority URA, 2001, Concept plan 2001. Singapore

-Urban Redevelopment Authority URA, 2004, Annual report, 2003-2004, p. 52

-Urban Redevelopment Authority URA, 2005, Skyline, May-June issue

-Wong, T-C, Guillot, X., 2005, A roof over every head: Singapore's housing policies in the 21 st century between state monopoly and privatization. IRASEC, Studies on Southeast Asia \& Sampark, Calcutta

-Yuen, B.,1998, (ed) Planning Singapore: From plan to implementation, Singapore Institute of Planners, Singapore

Table 1: Growth of Condominium Units, 1980-2002

\begin{tabular}{|c|c|}
\hline Year & $\begin{array}{c}\text { Number of Condominium } \\
\text { Units }\end{array}$ \\
\hline 1980 & 3,364 \\
\hline 1990 & 18,739 \\
\hline 2000 & 70,572 \\
\hline 2002 & 81,738 \\
\hline
\end{tabular}


Source: Department of Statistics (various years).

Yearbook of Statistics. Singapore.

Table 2: A Comparison of Condominium and Public Housing Developments, 19802002

\begin{tabular}{l|c|c|c|c}
\cline { 2 - 5 } & Year & $\begin{array}{c}\text { Number of } \\
\text { HDB units }\end{array}$ & $\begin{array}{c}\text { Number of } \\
\text { condominium units }\end{array}$ & $\begin{array}{c}\text { Ratio of condominium } \\
\text { to HDB units }\end{array}$ \\
\cline { 2 - 5 } our & $\$ 980$ & 372,640 & 3,364 & $0.9 \%$ \\
\cline { 2 - 5 } ce: & 1990 & 623,820 & 18,739 & $3.0 \%$ \\
\cline { 2 - 5 } Dep & 1995 & 700,060 & 34,908 & $5.0 \%$ \\
\cline { 2 - 5 } & 2000 & 846,650 & 70,572 & $8.3 \%$ \\
\cline { 2 - 5 } & &
\end{tabular}

art

ment of Statistics. Yearbook of Statistics. Singapore.

Various years.

Table 2 draws a comparison between developments of public housing and condominium. The spectacular progression of condominiums during the first seven years of the 1990s reflects the economic vitality of Singapore that had bolstered upper housing market demand until it was hit by the 1997 financial crisis. This increase in the production of condominium units must also be associated with the evolution in the type of developers engaged in their financing. In the early years of condominium development, it was small private entrepreneurs who were involved. Gradually more large private local firms took the lead, in particular 'private-public firms' such as CapitaLand, Keppel Land and Singapore Land. The leaders of private developers are Far East Organization, City Developments, Wing Tai etc.

i Today, northern European countries appear as leaders of such attempts with some flagship experiences such as the Vauban District in Fribourg en Bresau (Germany).

ii In Amsterdam, pour préserver les sols agricoles, le choix a été fait d'urbaniser le lac d'lj au nord de la ville, et de réinvestir un savoir anciens concernant la maitrise technique du sol artificiel. Chaque ile assure une spécificité dans le choix des densités bâties et des formes ou dans l'identité paysagère. Les îles résidentielles principales s'urbanisent par la conjugaison de deux figures apparemment contradictoires : celle de la grille urbaine avec ses ilots denses et celle de la ville-parc. In Orestäd in Copenhagen, c'est le concept de ville linéaire structurée autour d'un métro aérien qui a été retenu. La figure territoriale de la ville linéaire (sur $5 \mathrm{~km}$ de long) permet de relier la ville centre de Copenaghen à l'aéroport, en croisant en son milieu l'axe autoroutier connectant le Danemark à la Suède.

iii "Tout l'environnement morphologique et social dont émerge, en Angleterre, le thème de la cité jardin vient ici [ à Singapour ] se projeter, à l'écart de la société industrielle des métropoles européennes, mais dans l'univers industrieux qui en constitue la retombée locale - la ville asiatique, compacte, surdensifiée, faisant figure d'« équivalent symbolique » des quartiers ouvriers de la métropole ».

iv "La cité jardin préconisée par Howard, qui en faisait une description précise mais peu réaliste est imprégnée d'une réaction malthusienne (30 000 habitants, plus 2000 agriculteurs dans la ceinture verte) et ruraliste (la ceinture verte qui entoure la cité-jardin a pour buts de produire l'alimentation des citadins et d'éviter toute conurbation) à la ville industrielle et à sa banlieue. Elle se veut autarcique, assurant la diversité des tranches d'âge, des groupes sociaux et des activités de production, afin d'atteindre un équilibre et d'être 
autosuffisante, sur le plan alimentaire comme sur celui des produits industriels ", in Merlin, P., Choay, F., Dictionnaire de l'urbanisme et de l'aménagement, Quadrige/Manuel, 2005, p. 174.

$\checkmark \quad$ In another paper Savage (Savage, 1992, p.189) develops the idea that "Singapore's success as an environmental friendly city is a product of the political leadership's pragmatic environmental ideology that is hinged on possibilistic and anthropocentric human-nature relationships". I have used the concept of environmental possibilism in contrast to environmental determinism in the sense that human beings, societies and civilisations are not influenced by environment. Possibilism is a school of thought which upholds the view that humans, by virtue of their culture, intelligence, pragmatic philosophy, technology, organisational abilities, among other things, are active participants in human-nature relations.

vi Facilities include a swimming pool, gymnasium and a tennis court. There are only 69 apartments and, except for the penthouse apartment, they are all four-room duplex apartments of the same design, each covering an area of $256 \mathrm{~m}^{2}$.

This idea of multi-purpose habitat has some American antecedents. One of the pioneer examples of such a building is Marina City, in Chicago, designed by Bertrand Goldberg (competed in 1967). Despite the change of scale (the buildings by Goldberg are much higher) one finds the same design principle for the tower apartment, as well as the presence of various private services and facilities.

vii At the beginning of the 1980s, only 26 projects had been completed, providing a little more than 3,000 private apartments. At the end of the 1980s, 16 years after the introduction of the condominium ruling, one could count almost 20,000 condominium apartments. The real boom of condominium development occurred in the 1990s between 1990 and 1999, their production tripled and reached 60,000 units, and by 2002, the total available number exceeded 81,000 units

viii In the 1970s, private housing was mainly low-density individual housing (bungalows or terrace houses, semi-detached houses). During the 1980 s and 1990s, a radical change took place in favour of medium-density condominiums and apartments in the private residential market. In 2000 there were twice as many apartment units $(127,000$ units) than low-density individual housing $(65,900)$ (statistic to be updated).

ix This choice of location is also in line with the logic of enhancement of existing built environment through infill projects on vacant parcels. It follows an original concentric development pattern, leading to spread of condominiums to outlying areas. In the 1980s one may identify three condominium zones in and next to the city centre:

a) The first zone originated from bungalow residential type, located close to the city centre. It spreads across the residential district of River Valley Road, south of the city centre. Condominiums are grouped along this main road, which gives access to Leonie Hill;

b) The second zone is the residential district of Tanglin, west of the city centre; and

c) The third zone is the residential district of Holland Village, in the west, as a continuation of Tanglin.

a) The Main Upgrading Programme applies to housing blocks, which were constructed more than 18 years ago. Upgrading work includes the addition of new rooms in the apartment by adding prefabricated elements to the façade as well as adding various facilities, including a multi-storey parking building. These works are largely subsidized by the government and the inhabitants pay only a small share of the cost.

b) The Interim Upgrading Programme applies to housing units of 10 to 17 years old. In this case, upgrading work applies essentially to common areas, to access in particular, and the cost is only partially paid by the government.

c) The Redevelopment and Selective En-Blocs Renewal (SERs) Programme applies to the oldest housing units. In this case, upgrading means in most cases the demolition of the blocks and their reconstruction according to current HDB standards of comfort. Inhabitants are therefore re-housed in other apartments during the period of construction, contrary to the two other programmes, in which inhabitants continue to live in the block during the upgrading work. 
xi The first new town, which reflects the model rather well, is the Tampines New Town. In line with the precinct concept, a structural model of new town was developed. This model incorporated the more recently developed planning principles and criteria within the distribution principles of the earlier model. Basically, the structural model should help to better interrelate and integrate the various planning standards for facilities, continuously being developed, tested and updated. It has been successfully applied.

xii Under the revised Act 1997 of the ECHS, a series of rules and regulations were laid down under the jurisdiction of the Minister for National Development and the eligibility conditions to purchase an executive condominium are subject to:

a) Singapore citizenship, family nucleus and non-ownership of private residential property;

b) The income ceiling for an eligible household is $\$ 10,000$ per month; and

c) EC owners will no longer be able to buy flats direct from HDB.

Buyers of an executive condominium have to pay 20 percent down payment in cash while the remainder can be settled by monthly instalments through CPF deduction chargeable at commercial interest rates, which are higher than HDB 3- to 5-room rates. New occupants are obliged to occupy the apartment for at least five years, before being able to resell it to another Singaporean or permanent resident household. This measure aims to slow down speculative investments based on rapid buying and selling of apartments, which is a common practice in the private condominium market. After an additional five years, they can sell it to foreigners as well. Strata titles in the form of private property will only be issued after 10 years of occupancy.

xiii Located along the northeast coast of the island, the total area to be developed is 957 ha on which it is planned to build 85,800 housing units and various facilities. Housing occupies 50 percent of the entire site. The rest of the site is occupied by commercial and institutional buildings $(6 \%)$, public and leisure spaces $(14 \%)$, road infrastructure (15\%), water features (12\%) and land reserved for future development $(3 \%)$.

xiv This ratio clearly shows the importance given by the authority to the private sector in the overall construction of the new town. Indeed, if one adds the volume of private condominiums to the volume of executive condominiums (which in the short term will be considered as private housing), a total of 30,000 apartments or 35 percent of new town housing stock has been achieved.

xv Kallang Basin will be a sanctuary for water sports. You can choose between water skiing and windsurfing or simply decide to canoe quietly down for a change of scenery. The riverside promenade, stretching two kilometres, allows for the romance of wining and dining by the waters and long leisurely strolls fanned by cool sea breezes. There would also be a landing point, making boat cruises possible within the Basin, with connections to the waterways of Marina Bay and the Singapore River. When completed the leisure hub at Kallang Basin is set to make a big splash with its entertainment and recreation variety'. Urban Redevelopment Authority. 1993. Kallang Planning Area, Planning Report 1993. Singapore. p.11.

xvi The architectural design competition to build the Tower "Phare" designed by Thom Mayne in Paris La Defense (to be completed in 2012) is significant of this evolution. 